\title{
前庭感觉刺激を用いた歩行誘導効果と それに影響を及ぼす行動決定過程のモデル化
}

\author{
渡邊 紀文 $* \cdot$ 三門 裕明 $* \cdot$ 大森 隆司 $*$
}

\begin{abstract}
我々は日常生活において，矢印やサインなど様々な誘導を受けており，その多くは意識下で制御されて いる。そこで我々は新たな誘導デバイスとして，個人への適応が可能な前庭感覚刺激 (Galvanic Vestibular Stimulation) と呼ばれる，前庭感覚を電気刺激することで，身体を左右に傾かせるインタフェースを用いた 実験を行った。GVSを用いた歩行誘導として, 先行研究では電流量と左右の誘導量の評価を行っているが, 歩行速度及び誘導が開始するまでの潜時の評価は行われていない。そこで本研究では，歩行速度の変化に ついての定量的な評価及びその潜時の調査を行った。更に実験結果から，その誘導効果に対する歩行者の 歩行周期の影響が明らかになったため，歩行時の行動決定過程を理解するためのすれ違い行動実験を行っ た。具体的には視線情報から回避判断を行うときの対向者の身体部位及び対向者の歩行位相を明らかにし た，また歩行者自身の運動を計測し，回避運動を行う際の歩行者の歩行位相の影響について評価した。こ れらの結果から，歩行周期に基づいた歩行者の誘導方法について検討した.
\end{abstract}

キーワード：前庭感覚刺激，歩行誘導，すれ違い行動，行動決定過程

\section{1.はじめに}

人は望むと望まざるとに係わらず，多くの誘導 (guidance)を受けている。日常生活においても，新た な環境では駅やビルにある出口のサインに導かれて歩 くことが多く, 誘導員の指示も受ける。このように誘 導は生活の多くの場面で現れ，その種類も多岐にわた る。従って，より良い誘導方法を見いだすことは工学 的に有意義なことだけでなく，人間の行動決定への深 い理解も与える.

より良い誘導方法について議論するにあたり，一般 の誘導について, 次の 2 つの視点からの分類を考え る。第一は, 誘導される側の意識の有無である。第二 は，誘導が身体の全体に作用するかどうかという視点 である。このような分け方をした場合，そのほとんど が意識に上る誘導である。また，身体の一部のみの誘 導も少ない。前述の例でも，誘導し運動を伴わせる対 象は全身であるものが多い。身体の一部の誘導の事例 は特殊な技能の習得やスポーツの教示以外には多くは ない $[1]$.

では，意識下の誘導や，身体の一部に対する誘導が 不要かというと，そうではない。新たに身体的な技能 を獲得する場合や，多様な情報から自分の行動を決定

$\dagger$ Guiding Effect of Human Waking and Behavioral Decision Model by Galvanic Vestibular Stimulation

Norifumi WATANABE, Hiroaki MIKADO and Takashi OMORI

* 玉川大学脳科学研究所

Tamagawa University Brain Science Institute
する場合などの自由度の高い環境においては，自己の 行動により周りの環境がどのように変化するかを重視 し，その環境に自己の行動を適応しようとする。その ため自己の行動に特に意識を向けることが多くなり， それを補完する形で無意識的な誘導が有効になること が多く存在する。例えば初めて入った建物から出る場 合に扎いても，自分で出口の誘導サインを見つけて意 識的に誘導されるよりは，日常歩行しているときと同 様に自己の注意を向けているだけで歩行を誘導されて いる方が自己をコントロールしやすい，車にしても， 初めて通る道路に扔いて, 自己の注意が意識下で誘導 され，障害物を避けることが出来るのであれば，プラ ンニングなどのより高次の運転処理のみに集中するこ とが可能となる。このように無意識的な誘導を利用す ることで, 人の環境に対する適応機能を向上させるこ とは，意識するために必要な注意資源を減少させ，よ り高次な行動プランニングのために注意を有効利用す るということが可能となる。

このような意識下での誘導を実現する方法の一つ が，人間の錯覚を使うことである、錯覚を使用するこ とで人間の身体のフィードバック系に働きかけ，無意 識に行う運動の軌道だけを変えることができる。人に とっては日常の動作をしていても，知覚する入力側を 変化させ, 結果として得られる運動を変化させる方法 である。そのような感覚入力の変更による誘導方法と して, 本研究では前庭感觉刺激(GVS) を用いた歩行誘 導を検討する [2]，GVSは前庭に作用し，知覚する重 
力方向を変化させることが知られている $[3]$ ．この作 用により，意識して実行しようとする運動に対して， 実行する運動が無意識に異なる状態を生み出す。つま り無意識に運動を誘発し，そこから動作を修正する方 向で誘導するのである。このような錯覚を利用した誘 導は，「模倣」のような他者との相互作用により意識的 に獲得した動作に比べ，運動を出力するタイミングの 個人差が少なく，身体動作を制御する手法としても有 益であると考える.

本稿では第一に, この歩行運動におけるGVSの誘導 効果を, 歩行速度を変化させることで評価し, GVSが 影響を与える前庭感覚と運動との時間的な関係及びそ の効果を与えるための制御方法について議論する.

更に我々は，GVSによる歩行誘導及びその後行った 手先誘導の研究から，GVSは連続な周期運動において 大きな誘導効果が得られるのではないかという仮説を 得た。そこで次に, 歩行運動を連続な周期運動ととら え, 歩行運動に打ける行動決定過程の理解を目指した 実験を行った。これにより, 歩行時における環境の知 覚と歩行運動生成の動的過程のメカニズムを理解し, 意識下での誘導効果が最も得られる歩行位相及び誘導 タイミングを明確にした。

\section{2．前庭感覚刺激(GVS)を利用した歩行 誘導}

前庭感覚とは, 重力と加速度を検出し, 主に平衡感 覚を司る感覚である。前庭感覚は半器官と耳石器(卵 形囊と球形囊) で構成され, 半器官は 3 個の半規管が 空間の 3 平面に配置されたことで, 各方向の回転加速 度を感知し, 耳石器は重力や加速度を感知する。医療 分野では, 前庭感覚を耳に温水や冷水を入れることで 刺激し, 平衡感覚の機能の検査を行っている $[4]$ 。こ の前庭感覚を電流で刺激する事を, 前庭感覚刺激 (Galvanic Vestibular Stimulation, 以下GVS)という [5]. 具体的には, 左右の耳の後ろ (頭部乳様突起部) に電極を装着し, 微弱電流(数mAの直流)を流すと, 装着者の身体が陽極側に傾くという現象である [6] [7].

このGVSを利用し，歩行動作を左右に誘導する研究 が行われ, これらの研究ではGVSの電流量に対応した 左右の誘導効果を定量的に評価していた $[8][9]$ ．ここ で前庭感覚による自己運動感覚は時間応答が早く, 遅 れ時間が小さい，例えば半規管による自己回転運動感 覚の感度は, 自己運動感覚が引き起こされるときの回

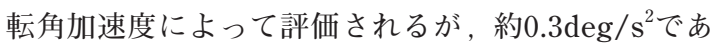
ることが示されている[10]. 更に前庭感覚は, 速度に 反応する持続性のシステムではなく, 加速度に反応す

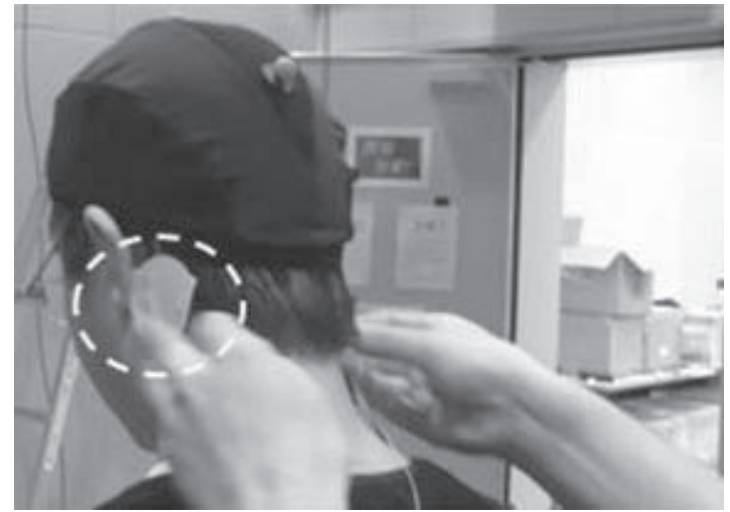

図1 GVSインタフェース

る一過性のシステムである。 そこで本研究では, 歩行 時の加速制御時においてGVSの効果が現れる潜時, ま た高速歩行と低速歩行という加速制御が異なる歩行で のGVSの誘導効果を定量的に評価する.

このような評価は, 歩行時の自己運動感覚に対する GVSの効果を示すこととなり, また多様な状況により 速度を変化させる日常の歩行運動への工学的応用に向 けて解決すべき課題であるといえる。

\subsection{GVSインタフェース}

前庭感覚に電流を流すGVSインタフェースは, 低電 流回路としてカレントミラー回路を使用し, 安定した 電流を実現している. 出力にはHブリッジ回路を使用 し, 単一電源で電極の極性を任意に選択可能であり,

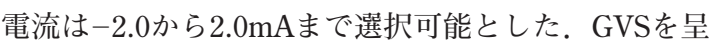
示する際, 被験者の肌の頭部乳様突起部と接触させる 電極には, National社製のゲル電極(サイズは $50 \mathrm{~mm} \mathrm{x}$ 40mm)を使用した(図 1 参照).

ここで半規管は内リンパ液に満たされた円環状の管 であり, 自分自身が回転運動をすれば頭が回転し, 頭 の回転によって内リンパ液の流動が引き起こされる.

この内リンパ液の流動が前庭神経を刺激し, 自己運動 感覚を検知する。本GVSインタフェースは頭部乳用突 起部からの電流刺激により内リンパ液の流動に変位を 生じさせ, それにより頭部回転運動の自己運動感覚を 引き起こす［11］[12］。これにより，回転運動を補正す る形で頭部及び身体運動を引きおこし, 誘導を生じさ せる、本研究では, 上記のGVSインタフェースを用い て, 歩行誘導を行った。

\subsection{GVSによる歩行実験}

GVS呈示後の左右方向への移動距離を定量的に評価 するため, 歩行中にGVSを呈示した際に, GVSが何 時, 身体のどの部位に影響を与えるのかを計測し, 身 
体動作の変化とその潜時を計測した。更に歩行速度を 変えた時の影響を調べるために, GVS呈示後の移動距 離を, 高精度のモーションキャプチャシステムで計測 した。

実験では, まず頭, 肩, 腰, 足などの身体部位間で の移動距離及び誘導効果が現れるまでの潜時をモー ションキャプチャシステムで計測した。モーション キャプチャシステムはMotionAnalysis製で，カメラは 12台, キャリブレーション後の計測誤差は $0.5 \mathrm{~mm}$ 以 下，サンプリングレート $250 \mathrm{~Hz}$ の精度である，GVSを 利用した歩行時間に対する歩行速度と距離の関係を評 価するため, GVSインタフェースとモーションキャプ チャシステムを同期させ, GVSの刺激時間と左右への 移動距離を計測した。計測部位は, 頭 3 点, 両肩 2 点, 両肘 2 点, 両手首 2 点, 両腰 2 点, 両膝 2 点, 両 足首 2 点の計15点である.GVSによる左右方向の距離 は被験者 3 名で評価し，潜時及び一定時間での移動距 離を比較した。

GVSによる電流刺激は，0sから0.5sにかけて0mAか ら1.5mAに遷移し，0.1間 $1.5 \mathrm{~mA}$ の定常值を保ち， $0.6 \mathrm{~s}$ から $1.1 \mathrm{~s} に 1.5 \mathrm{~mA}$ から $0 \mathrm{~mA}$ に遷移する台形波を用 いた(図 2 参照).

実験では被験者にGVSインタフェースを装着し, 被 験者は実験室内を前方に 9 歩歩行した。その際歩幅を

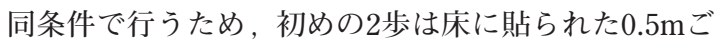
との指標を踏み, 2 歩目以降は閉眼するように指示し た。閉眼するまでの視線は $0.5 \mathrm{~m}$ 先の次の指標とし, 閉眼しても同じ姿勢を保つように指示した。また歩調 はメトロノームの音に合わせるよう指示し, 歩行を始 めてからメトロノームの 4 回目の音, つまり歩行でい う4 歩目にGVSを呈示した。メトロノームのテンポは 110 回/分 (以下高速歩行) と, 90 回／分 (以下低速歩 行)で行い，それぞれ右側にGVSを呈示する場合(右側 陽極），左側にGVSを呈示する場合 (左側陽極)，GVS なしの各条件を各 10 回, 計 30 回の試行をランダムに 行った.

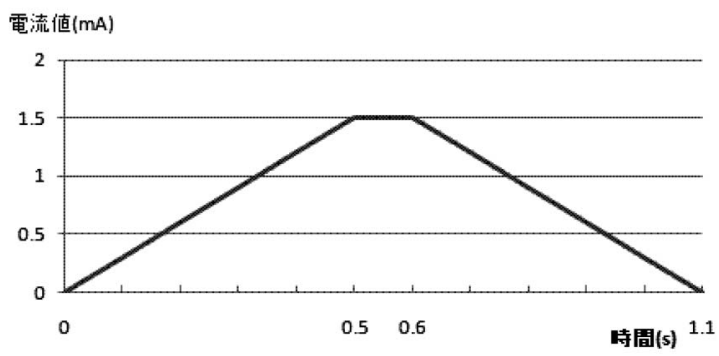

図 2 GVSの電流波形

\subsection{1 実験結果}

GVSを呈示する瞬間の左右の移動距離を 0 とし, GVSを呈示し始めてから 2 秒後の左右の移動距離を求 め, GVSなし, 右側陽極, 左側陽極の左右の移動距離 を計測した結果を図 3 に示す。実験データの解析で は, 移動距離を計測するため計測部位で最も長時間計 測可能であった肩の座標を用いた。

図 3 の結果から，GVSを呈示していない時とGVSを 呈示した時の左右の移動距離に差があり $t$ 検定の結 果からも有意な結果 $(p<0.05)$ が得られた。また, 電 極の極性を変更することで逆方向に誘導する事が可能 であったことから，陽極に誘導される事も確認した。 これは被験者全員にいえ，また高速及び低速歩行実験 両方に扔いて同じ結果が得られた。この事から，GVS を用いて, 高速歩行と低速歩行の両方において, 左右 方向の誘導が行えたといえる.

次に計測部位間での誘導タイミングを評価し，それ ぞれの刺激呈示から誘導効果発生までの潜時を求め た，GVSを呈示する瞬間の時間と距離を 0 とし, GVS なしとGVSを呈示した時の単位時間当たりの左右への 平均移動距離を $t$ 検定し, 初めて $5 \%$ 有意になった時 間を潜時とした。その際GVS呈示後の単位時間当たり

(a)

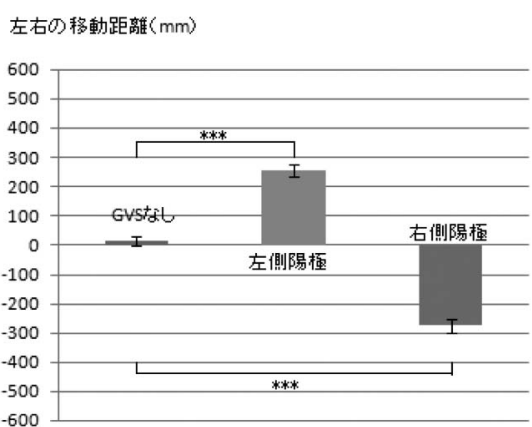

- GVsなL 左側陽極 右側陽糧 (b)

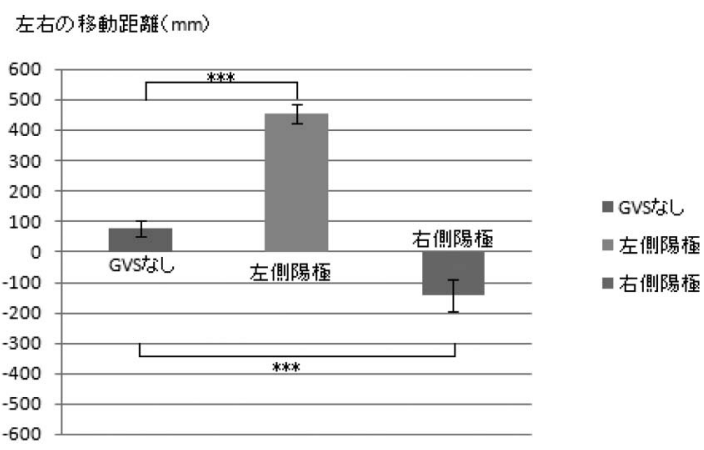

図 3 高速歩行時の左右方向への移動距離(a). 低速歩 行時の左右方向への移動距離 (b). 
の移動距離の平均が，GVSを呈示していないときの移 動距離より陽極側に值が増加した時から検定をかけ た。頭，両肩の中心，両腰の中心と，両足首それぞれ の潜時の結果を図 4 に示す。図 4 (a) は, 被験者間で の身体部位の潜時を比較した結果である。被験者毎の 潜時には差があるが, 頭, 肩, 腰, 両足の身体部位毎 の潜時には差が見られなかった，次にGVSの左右の極 性と，身体部位間の潜時を比較すると(図 4 (b)), 頭, 肩, 腰では極性による潜時の差は見られないが, 両足については左右の極性による差が見られた。具体 的には左側陽極時には左足の潜時が約 $0.4 \mathrm{sec}$ ，右側陽 極時には右足の潜時が約 $0.3 \mathrm{sec}$ 長くなった。成人では 通常歩行速度に打いて 1 歩を約 $1.0 \mathrm{sec}$ で歩行を行うた め, $0.3 \sim 0.4 \mathrm{sec} の$ 遅れは半歩程度の誘導発生の遅れ と考えられる。このことから，GVSによる潜時では， 刺激呈示時に左右どちらの足で踏み出しているかとい う歩行周期の影響と，GVSの極性を考慮する必要があ る.

次にGVSを呈示する瞬間の左右の移動距離を 0 と し，GVSを呈示してから 2 秒後の高速歩行と低速歩行 の左右の距離を比較した結果を図 5 に示す。ここで 「GVSなし」の試行において歩行時に左右に移動してい

\section{(a)}

\section{寺间(s)}

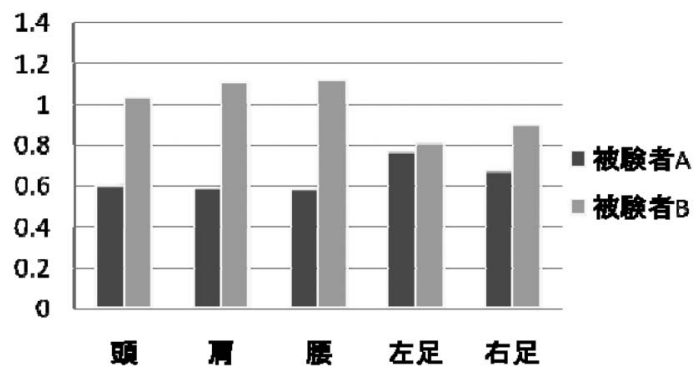

(b)

\section{时四(s)}

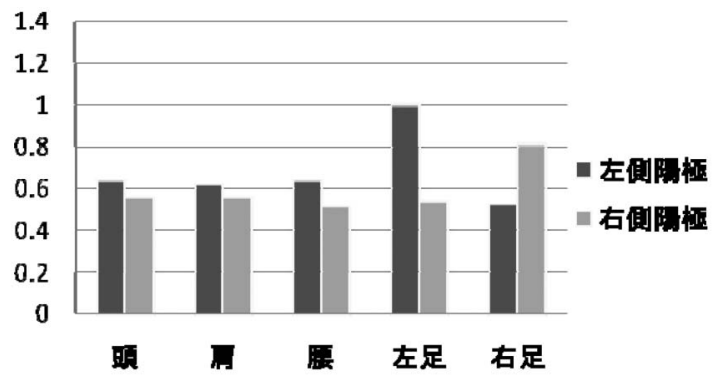

図4 被験者間での身体部位の潜時の比較(a)。GVS呈 示から身体部位(頭, 肩, 腰, 左足, 右足)が移 動するまでの潜時(b).

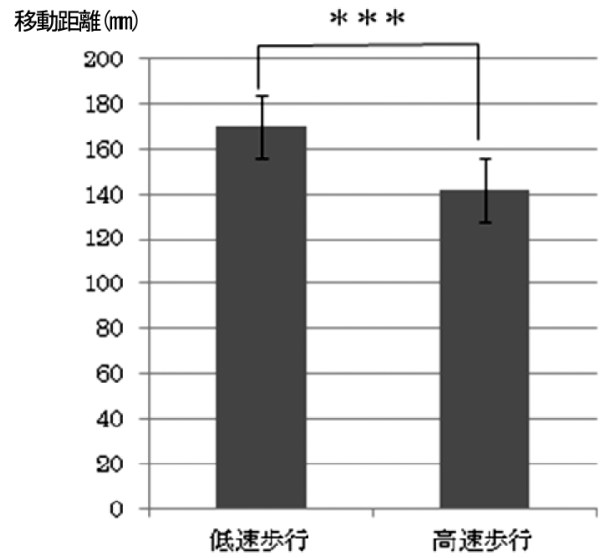

図 5 GVS呈示から 2 秒後の高速歩行及び低速歩行時 の移動距離

るため，GVSを呈示した時の距離は，「GVSなし」の移 動距離の差分で分析を行った。図 5 から高速歩行時に 比べ低速歩行時に誘導される距離が長いという結果が 得られた。

\subsection{2 考察}

実験結果から, 本実験で行った高速歩行及び低速歩 行に扣いてもGVSを呈示した陽極方向に身体を誘導す ることが可能であった. 更に, 誘導を行う時の潜時に ついては，移動距離の個人差は見られたが，頭，肩， 腰, 両足の身体部位間に潜時の差は見られなかった。 但し個人内での潜時を比較した所，両足について呈示 した極性により潜時が異なるという結果が得られた。 潜時は約半歩程度の遅延であるため，1歩進むときの 足の状態(歩行位相)により, GVSの影響が現れやすい 位相と, 影響が現れない位相があるのではないかと考 えられる。

次に歩行速度に打ける左右の移動距離の結果から， 高速歩行と比較し低速歩行時はGVSにより誘導される 距離が長くなる傾向が確認された。更に単位時間あた りの移動距離が長いという結果から, 左右への移動距 離の変化量については, 高速歩行時は小さく, 低速歩 行時は大きいといった相関関係が見られた。これらの 結果から, 歩行速度により誘導される距離の変化量が 異なり, 歩行速度が遅くなることで, 距離を増大させ ることが可能であると考えられる。

本結果から得られた結果と, GVSの平衡感覚への影 響から，我々は以下のような仮説を得た。GVSは電気 刺激を用いることで電流が流れた方向に加速度が増大 し，被験者は身体が傾いたと錯覚する。この傾いたと 錯覚した知覚情報を平衡感覚が検出し，その身体のバ 
ランスを補正する方向(電流が流れた方向と逆方向)に 身体を傾かせることで姿勢を安定しようとする。この 補正をする方向に身体が傾くことで，歩行中に左右へ 身体バランスが崩れ，左右方向への移動が起こるので ある。

ここで歩行中は, 平衡感覚は足裏からの重力の知覚 フィードバックを常に受けており，歩行中の足の状態 (歩行位相)によってその知覚フィードバックからの情 報の大きさは变化する，具体的には右足が遊脚で，左 足が着地している，また右足が着地して打り，左足が 遊脚である状態は，それぞれ着地している足からの知 覚フィードバックが大きくなり, GVSの影響が増大す ると考えられる。そこで，身体部位間でのGVSによる 潜時の差が両足でのみ現れたと考えられる。また歩行 速度の影響についても，高速歩行に比べ低速歩行時は 片足が着地している状態の時間幅が大きくなると考え られるため，GVSの影響も大きくなる，そこで低速歩 行時において，単位時間あたりの左右方向への移動距 離が増加したと考えられる。このようなGVSと平衡感 覚からの知覚フィードバックが変化する周期運動の関 係は，他に手先運動の誘導でも検討されており，不連 続の多い運動であるダーツ投擲においては，GVSによ る誘導の効果は現れなかったが，連続的な周期運動で ある円描画課題では, 誘導効果が現れたという結果が 得られている[13].

そこで次に我々は，GVSを用いたより効果的な歩行 誘導を実現するため，日常的な歩行運動である人との すれ違い歩行時の行動を分析し，歩行周期という観点 から歩行者の行動プランニング及び運動生成という行 動決定過程のモデル化及び，それに基づいた特定の歩 行位相での誘導について検討した。

\section{3 .すれ違い歩行運動時の行動決定過程の モデル化}

我々は日常様々な感覚を取り入れて運動を決定する が，歩行時にはその中でも特に環境に対する身体の変 化量を検知する「視覚」, 頭部の回転及び角加速度を検 知する「前庭感覚」, 身体の各部位の相対位置関係や足 裏部の圧力分布を検知する「体性感覚」に依存して行動 をする $[14]$ ，その中で特に重要なものとして視覚が挙 げられる，日常生活において，我々は視覚からの情報 を取り入れ，その情報を基にして行動を決定する。一 方で, 例えばパニック状態に陥った場合, 視野が狭く なり，周辺の情報が入らず行動ができなくなる時があ る。結果として大きな集団に群がり，そこから小さな 集団に分散することや，単独で新たな行動をする事が 困難になる $[15][16]$ 。このような歩行に打ける自由な
行動の問題は，歩行者自身がプランニングする意識的 な行動に対して, 適切な方向へ無意識的な視線の移動 及び身体の誘導を与えることで，軽減することが可能 であると考えられる。このような人の歩行運動を，外 部から適切なタイミングで誘導するためには, 歩行者 の行動決定過程を理解する必要がある.

これまで人間の歩行や行動決定に関連する研究は数 多くなされているが，午の中でも混雑した会場にいる 人間の群集誘導を目的とした，すれ違い行動研究があ る. 中村らはグループ間でのすれ違い行動を明らかに するため, 博覧会などの大規模集客施設に集まる歩行 者グループについて，すれ違いの際に打こる行動の傾 向を調査した $[17]$. 結果として, 一定数以下の歩行者 グループは, 対向者が多ければ多いほど大きく避ける 傾向があり，一定数以上の歩行者グループである時 は，数が多いほど直進する傾向があることを指摘し た。しかし実際にすれ違う時に, 集団がどのような環 境の影響を受けているのか，また対向する集団のどの 部分を観察して行動を決定し, 運動しているのかと いった，すれ違い時の行動決定過程については検討さ れていない.これらの行動原理を理解しなければ, 個 人を含んだ集団に対しても適切な誘導を実現すること は困難である。

そこで本研究では, 最も単純な状況として 1 対 1 の すれ違いを取り上げ，回避判断のタイミングや回避判 断に必要な情報を明確にすることで, 歩行時の行動決 定過程のダイナミクスについて検討する.

\section{1 すれ違い時の歩行運動のプランニング}

本研究では，すれ違い行動を二つの集団及び個人の 進行方向が，互いに平行かつ反対である際に起こる行 動と定義する。ここでモデルを単純にするため, 自己 は直進しており，他者が回避するために方向を変えよ うとしている場合を考える。この場合，他者は自己の 動きを観察し，そこから自己の回避方向についての意 四推定をすることで, 自身の行動プランを形成し, 運 動を実行していると考えられる。そこで本研究では， 回避行動をとる時に必要な情報を対向者の身体情報と 特定し, そこでの視線移動及び回避行動生成タイミン グから，歩行運動のプランニングを検討する.

\section{2 回避判断で注視する身体部位の評価}

人とすれ違う時, 我々は主に視覚から得られる対向 者の身体的な特徴から, 自己の回避方向を決定する. 本実験では, 回避判断時において対向者の身体部位か ら得られる情報を評価することで, 回避判断時に注視 する身体部位を特定する。 
被験者は，プロジェクターから約 3 メートル離れた 場所で対向者とのすれ違い動画を確認し，回避判断を 行う。実験者が動画を再生させた後，被験者は歩行を イメージするために足踏みをし，対向者の回避方向が 分かった瞬間に自分から見た相手の回避方向のボタン を押す。

使用した映像は, 約300試行のすれ違い映像につい て身体部位をマスキングした動画である。対向者の身 体部位を頭，上半身，足の 3 力所に分類し，そのいず れかをマスキングした映像を用いた(図 6 参照)。マス キング映像を用いることで，我々が通常中心視で観察 している身体部位からの情報を制限し，その制約に よって発生する回避判断の遅延時間から，す机違い判 断で重要となる身体部位を特定する。使用した動画 は，撮影者と対向者が同時に歩行を開始し，撮影者は 直進，対向者はあらかじめ指示した方向に回避行動を 行ったすれ違い映像である。映像は 4 名の対向者に対 して, 右側回避 20 回, 左側回避を 20 回ずつ撮影し, 回避判断を行う実験ではそれらを被験者にランダムで 呈示した。

図 7 は, 被験者 3 名について, マスキング映像を用

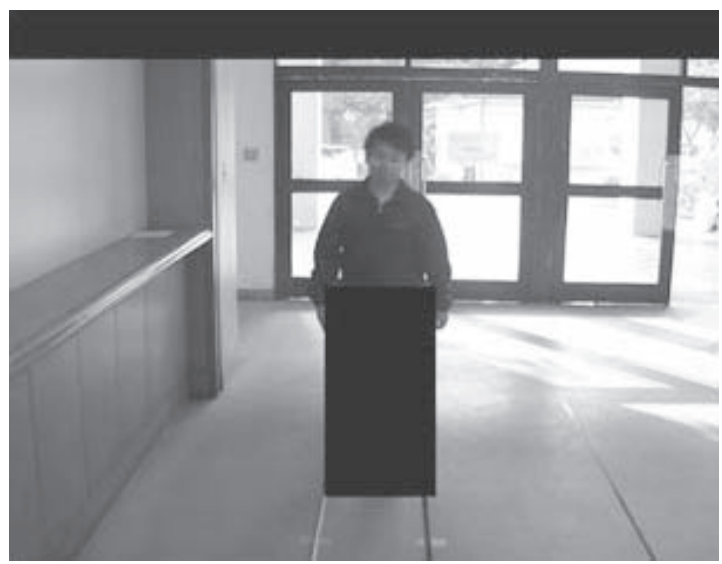

図 6 すれ違い回避判断実験における足元のマスキン グ映像

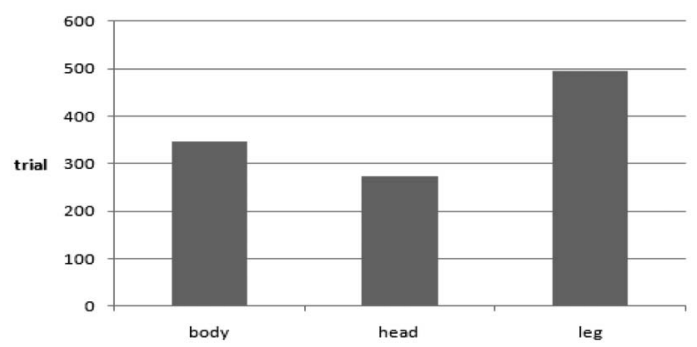

図 7 被験者が注視している対向者の身体部位 (上半 身，頭，足)
いた時に回避判断が最も遅れた身体部位の判断数を合 計したものである。結果より，足をマスキングする と，判断時間が長くなる傾向にあった。これにより， 我々はすれ違い時に足元の情報を利用して回避判断を 行っているということが示唆される。更に本実験結果 について，被験者毎の個人差は見られなかった。

\section{3 回避判断に影響を与える歩行位相の評価}

回避判断で注視する身体部位の評価実験から, 我々 は歩行時に主に足元を見て回避判断を行っているとい う結果が得られた。但し，頭や上半身をマスキングし たときにも判断にかかる遅延が起きたという結果か ら, 足元だけで判断が不可能となった場合に, 頭部や 上半身を見て判断をしているのではないかと考えられ る。例えば歩行時の左右の足の位置によって, 回避判 断を行う身体部位が異なるという事が考えられる，足 を上げた時，または足を着地するタイミングは，歩行 者が自身の足で歩行をコントロールする事が可能であ るため，その時は対向者の足元で方向を判断すること が可能である。しかし，足が着地及び上がりきってい る時は, 歩行者は足で方向をコントロールすることが 不可能であり，対向者の足以外の身体部位，すなわち 体か頭の向きで方向を判断すると考えられる(図 8 参 照)。そこで次に，回避判断に対する，対向者の足の 位置(歩行位相)の影響を評価した。

被験者は, 回避判断時に注視する身体部位を特定す る実験と同様，プロジェクターから約 3 メートル離れ た所で実験を行う。被験者は, 動画が流れた時に歩行 をイメージするために足踏みを開始し，プロジェク

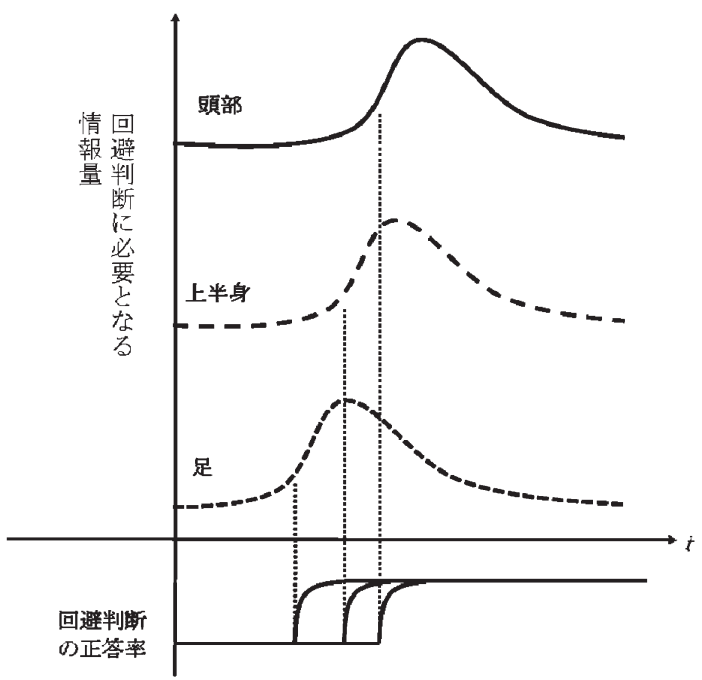

図 8 回避判断実験における判断で利用する身体部位 の情報量と正答率の関係困 
ター上に映っている対向者の回避方向が分かった瞬間 に，自分から見た相手の回避方向のボタンを押す。但 しこの時，回避方向の正誤は問わない，使用した動画 は，身体部位特定の実験と同様 1 対 1 のすれ違い状況 を再現したものであり，4人の対向者に対して右側回 避10回, 左側回避10回, 更に左右の踏み出す足を指 示して撮影を行った。実験は被験者 1 人につき 1 日 5 セットを 4 日行い, 撮影した計 160 試行のデータをラ ンダムに呈示して回避判断を行った。

実験で使用した動画の他に，対向者の足の位相を解 析するため, 対向者を横から撮影した動画を記録し た.ここで 5 回分の実験の判断時間より平均判断時間 を求め，その時間を基にして回避判断時の足の位相を 求めた。足の位相は左右それぞれの足を着地，遊脚前 期(踵を上げている状態)，遊脚期(足を上げている状

(a)

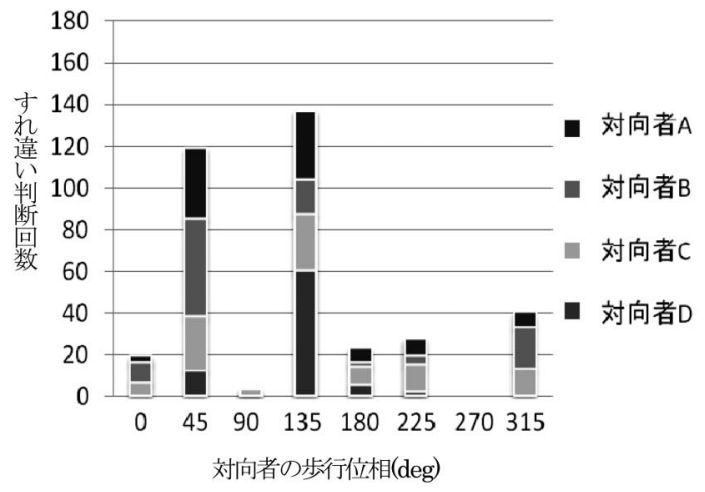

(b)

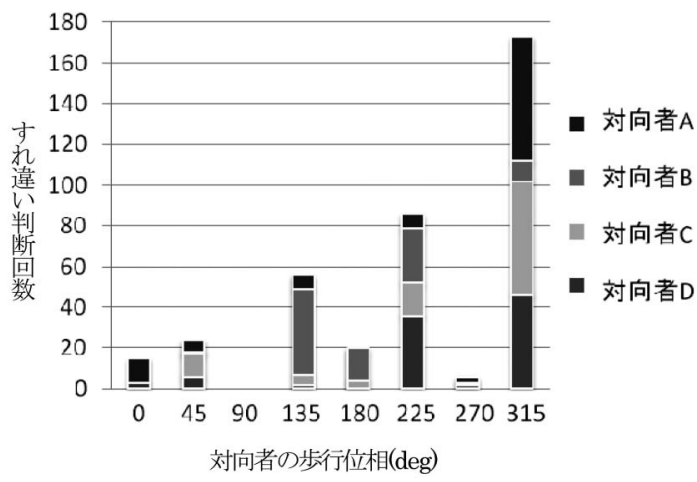

図 9 回避判断時の対向者の歩行位相 ( 0 : 左足遊脚, 右足着地，45：左足遊脚後期，右足着地，90： 両足着地, 135 : 左足着地, 右足遊脚前期, 180 : 左足着地, 右足遊脚, 225 : 左足着地, 右 足遊脚後期, 270 : 両足着地, 315 : 左足遊脚前 期, 右足着地). 対向者左足踏み出し時のすれ違 い判断回数 (a). 対向者右足踏み出し時のすれ違 い判断回数 (b).
態)，遊脚後期(つま先を上げている状態)の 4 つの状 態に分類し, グラフで表示する際は，「0：左足遊 脚, 右足着地, 45：左足遊脚後期, 右足着地, 90 : 両 足着地, 135 ：左足着地, 右足遊脚前期, 180 ：左足着 地, 右足遊脚, 225 : 左足着地, 右足遊脚後期, 270 : 両足着地，315：左足遊脚前期，右足着地」とした。

図 9 は被験者が回避判断をした時の各足の位相の判 断数を，4名の対向者A. B. C. Dに分けて表したグラ フである。困 9 (a) は, 対向者が左足から踏み出した 時の歩行位相毎の回避判断数であり，この場合， $45^{\circ}$ (左足遊脚後期) と $135^{\circ}$ (右足遊脚前期)の判断数が多 い. 一方, 右足から踏み出した場合は $225^{\circ}$ (右足遊脚 後期) と $315^{\circ}$ (左足遊脚前期)で判断している時が多い (図9 (b) 参照).これらの結果から, 足元を注視した 時のすれ違いでは, 歩行位相の中でも特に遊脚前期及 び遊脚後期において回避判断が行われていることが示 唆される。

\section{4 回避運動生成時の歩行位相の評価}

3.2 及び 3.3 の実験結果から, 対向者の歩行位相に よって回避判断を行う身体部位が異なる可能性が示さ れ, 回避判断に影響を与える歩行位相を分析した結 果, 片足が遊脚前期及び遊脚後期の場合に多く判断さ れていることが明らかになった。しかし, 自己の行動 決定過程では, 自己と対向者間の距離や自己の歩行位 相が影響を与える可能性がある。そこで次に我々は, モーションキャプチャシステムを使用してすれ違い時 の歩行者の身体を計測し, すれ違いのための身体運動 が開始されるタイミング及び歩行位相を評価した。

被験者と対向者間の距離を約 5.2 メトルとして, 対向者が手を挙げて下ろした時点から両者同時に歩行 を開始する。この時, 対向者及び歩行者はともに直進 する。そして, 被験者は予め指示されていた左右方向 に回避して, 対向者はそのまま直進してすれ違う。回 避距離は, 被験者には対向者と衝突しそうになったら 避けるように指示した。本実験では被験者 3 名につ き, 右側回避を10回, 左側回避を10回ずつ計測した.

被験者は左右に回避する際, 直進方向に対して左右 の速度べクトルが大きく変化する. 本実験では, 足首 の左右方向の速度が $100 \mathrm{~mm} / \mathrm{s}$ 以上移動した時を運動 生成タイミングとして評価した。眓10は各回避方向に おける運動生成タイミングでの歩行位相の頻度を3名 の対向者A.B.Cに分けて表したグラフである。本実験 では, 位相を遊脚前期, 遊脚, 遊脚後期, 着地の4位 相に分類し，3.3の実験と同様に0〜315の值でグラフ に表した。罒10（a）は, 被験者が左側に回避運動を 行った瞬間の歩行位相であり, 左足が遊脚から遊脚後 
(a)

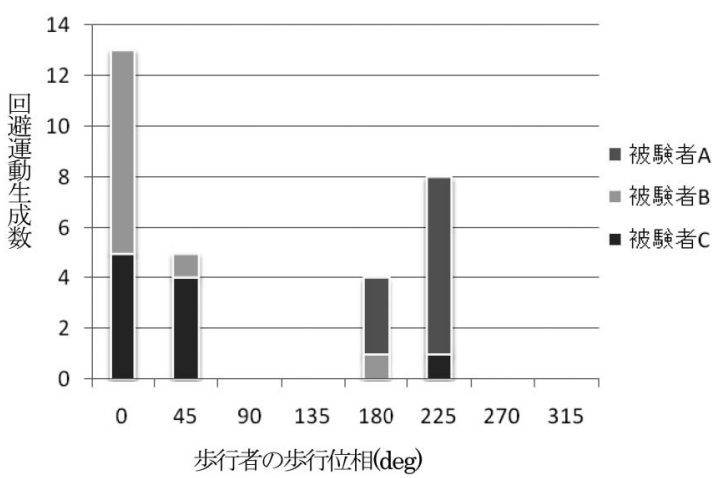

(b)

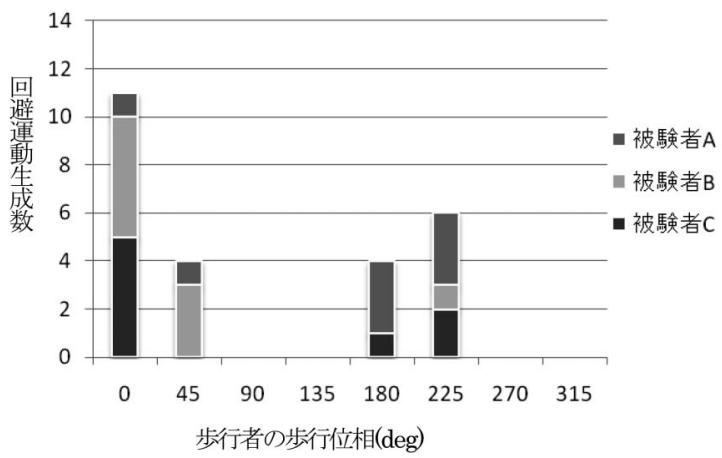

図10 左側回避の運動生成時の歩行位相 (a)。右側回避 の運動生成時の歩行位相 (b)

期，また右足が遊脚から遊脚後期において運動生成を 行っている。一方で図10(b) は右側に回避運動を行っ た瞬間の歩行位相であり，こちらも同様に左足が遊脚 から遊脚後期，また右足が遊脚から遊脚後期において 運動生成を行う場合が多い。以上より，回避運動を生 成する瞬間での歩行者の足の位相は，主に遊脚から遊 脚後期であることが示された。

\section{5 考察}

3.2 及び3.3の実験結果より, 我々はすれ違い行動を 行うとき, 主に対向者の足元を注視し, 更に対向者の 特定の歩行位相で回避判断を行っていることが明らか となった. 更に回避判断時の歩行位相の結果から, 歩 行者は，対向者が足の方向をコントロールできる遊脚 前期及び後期に打いては, 足元の情報から回避方向を 判断する. しかし，足の方向をコントロールすること が困難な着地時及び遊脚期においては, 歩行者は足だ けの情報では対向者の回避方向の意図を推定すること が困難であるため，自身の回避判断ができない，穴の 時は, 対向者の胸元や顔の向きによって, 回避方向を 判断すると考えられる.
更に3.4の実験結果より，我々がすれ違うための回 避運動をする際にも歩行位相の影響を受けていること が明らかとなった。具体的には遊脚期から遊脚後期の 位相で回避運動を生成しており，足を着地する前の瞬 間で足先の方向を制御していると考えられる.

これらの結果から,すれ違い行動時に回避判断を行 うための対向者の身体部位の情報及び，回避判断タイ ミング，また回避運動生成といったすれ違い行動の行 動決定過程に対して, 歩行位相が影響しているという ことが示唆された。

\section{4 . 歩行位相モデルに基づいた歩行者の誘導}

本研究は, 意識下での人間の歩行誘導を目指し, 第 2 章において, 前庭感覚刺激の錯覚で生じる身体運動 の変化を用いた歩行誘導実験を行った。実験を行った 結果, 歩行誘導では, 刺激開始から誘導が始まるまで の時間 (潜時)について, 歩行速度及び身体部位間での 差はないが, 個人差が見られた。これにより, 刺激タ イミングの個人適応が必要であることが明らかになっ た。次に歩行速度と左右方向への移動距離の関係を評 価したが，低速歩行時には単位時間当たりの移動距離 が長く, また高速歩行時には単位時間当たりの移動距 離が短いということが確認された。また個人内の各身 体部位における潜時を比較した所, 両足については GVSを呈示したときの極性が潜時の長さに影響を与え た。これらの結果から, 前庭感覚刺激は歩行中の重力 の知覚フィードバックの影響を受けており，特に影響 を強く受けやすい片足が地面と接地していない遊脚期 において誘導効果が大きくなるといった仮説が得られ た。そこでGVSによる誘導効果に影響を及ぼす歩行位 相を明らかにするため, 歩行者の歩行位相に基づいた 行動決定過程を議論することが必要となった。

\section{1 歩行位相に基づいた行動決定過程}

第 3 章において, 歩行運動の行動決定過程の理解を 目指し，1対 1 のすれ違い状況での行動計測実験を 行った。具体的には，すれ違い時の対向者の身体部位 (頭, 上半身, 足)をマスキングした映像を用いて回避 判断実験を行い，回避判断で注視する対向者の身体部 位を明らかにした。実験より, 我々がすれ違い行動を 行う際に, 対向者の足の位相により視線を向ける身体 部位が異なる，また歩行者自身が回避判断をするタイ ミングは, 対向者が着地する前後の足の位相 (遊脚前 期及び後期) に影響を受けるということが明らかと なった。また我々が回避運動を行うタイミングについ ても，自身の歩行位相の影響を受けて打り，足裏から の知覚フィードバックが大きい遊脚及び遊脚後期と 


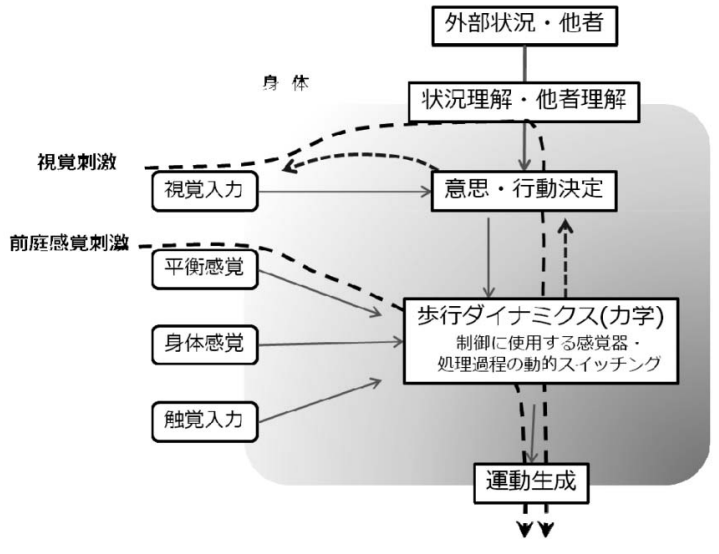

図11 歩行行動決定過程のダイナミクス

いった足を着地する前であることが明らかになった。

このような周期運動に基づいた行動決定過程のダイ ナミクスは，今回行った人とのすれ違いという特定の 状況だけではなく，我々の歩行運動一般で行われてい る過程であると考えられる。我々は歩行をする際, 尙 髄に存在する CPG (Central pattern generator)を利用 し，リズミカルな歩行運動を生成する [18]. この歩行 リズムを利用することで, 平地や階段, また人混みや 初めて歩く場所においてもスムーズで安定した歩行を することができる。今回実験を行ったすれ違いという 状況に抽ても，我々は他人がどのように動くのかを あらかじめ知らなくても安定して歩くことができる. これは我々が実時間で歩きながら人の動きを予測し， 避け方を計画しながら行動しているからである.

そこで今回行った研究からモデル化した，歩行運動 の行動決定過程を罒11に示す。まず我々は歩行をする ことで変化する外部環境，もしくは他者に関する大量 の感覚情報を得る。その情報から自分自身と環境との 相互作用を考え, 状況及び他者について理解をする. そこから必要な意思決定と行動のための運動指令を作 り出し，運動を生成する。ただし歩行は静的なもので はなく，移動を伴ったダイナミックな過程であるた め, 我々が行動決定した運動が直接環境に働きかけ, その結果環境からのフィードバックとして新たな感覚 情報を得る。受け取った感覚情報は次の行動を呼び起 こし，新たな運動が生成されるのである。

\section{2 行動決定過程における前庭感覚刺激の影響}

ここで今回誘導刺激として取り上げた前庭感覚刺激 は, 通常我々が意識してコントロールを行わない平衡 感覚に影響を与える感覚入力であり，入力された信号 に対して運動パターンがある程度定型化していると考 えられる。そのため, 我々が外部環境に対して持って
いる内部モデルに影響を与えずに, 誘導が可能である と考えられる。しかし歩行時においては，我々はより 重要な感覚情報として, 視覚情報を利用している。視 覚は, 歩行時において行動を生成する際に反射的な行 動をとるのみならず, 経験に基づき内部モデルを構築 し，それに基づく予測を行いながら行動を生成する。 そのため視覚情報が我々の行動, 更には意思決定に対 しても影響を与え, 歩行ダイナミクスが変化する。こ の視覚情報に基づいた内部モデルの調整と, 歩行ダイ ナミクスへの影響が最も強く表れたのが, 回避判断を 行う遊脚前期及び後期という歩行位相であると考え られる。更に第 2 章で述べた前庭感覚刺激の歩行速度 に対する影響においても, 視覚情報により前庭感覚刺 激による身体運動の変化を補正する新たな運動指令が 生成され, それが歩行位相に影響するため, 歩行速度 による誘導効果の違いが現れたのではないかと考えら れる。具体的には, 前庭感覚刺激により錯覚が起きた 左右方向への重心バランスの歪みが, 身体内部から得 られる情報として視覚に影響を与え, その外乱を補正 するような新たな内部モデルを構築することで新たな 行動のための指令を作り出し, 運動を生成する。この 運動生成を行う遊脚から遊脚後期は, 重力からの知覚 フィードバックの影響が大きくなり，特にその歩行位 相の時間幅が大きい低速歩行時には，新たな運動の効 果が大きくなると考えられる。

これらの歩行時における行動決定過程から, 前庭感 覚刺激を含めた意識下に影響を与える誘導デバイスを 効果的に利用するためには，視覚情報から得られた内 部モデルの形成に影響を与えないことが重要であると 考える。例えば今回取り上げた対向者とのすれ違い歩 行では，対向者の遊脚前期及び遊脚後期に対向者の回 避方向を判断した後に前庭感覚刺激を呈示し, 視覚情 報から得た行動決定及び運動生成の内部モデルに影響 を与えずに, 運動パターンが定型化している平衡感覚 のみに影響を与えて誘導するということである。これ により，前庭感覚などの意識下に影響を与える誘導デ バイスの効果を最大限に引き出し, 更に前庭感覚刺激 については知覚された平衡感覚を修正することで行動 が誘発されるため, 平衡感覚への影響を強調すること でより大きな修正運動が生成されると考えられる。

\section{5 . おわりに}

本研究でおこなった, 前庭感覚刺激などの知覚刺激 を用いた人間の感覚一運動モデルの研究は, 心理学, 認知科学, スポーツ科学の分野, 更に誘導という観点 では建築工学等でも研究が行われている。ただしこの ような分野の多くは, 意識的な知覚刺激を用いた研究 
であり, 本研究で目指した意識下で効果が現れる知覚 刺激を用いた研究例はまだ少ない。

無意識的な誘導を利用することは，感覚入力に対し て運動パターンがある程度定型化しているという理由 から，人の環境に対する適応機能を向上させることに も繋がり, 意識するために必要な注意資源を減少させ ることができると考えられる。一方で，今回取り上げ た歩行時における前庭感覚刺激と視覚刺激のように， 人間の意思及び行動決定に強く影響を与える感覚情報 が，他の感覚情報によって構築された内部モデルに干 渉し，身体に対する拘束を生むことでその運動効果を 減少させるということが起きる。このように，我々は 様々な感覚情報を用いて環境に適応した行動を生成し て打り，その影響も対象となる運動で変化すると考え られる。 今後もこのような知覚一運動ダイナミクスの 元での各感覚の特性を考慮したモデルの構築及び, 知 覚刺激を利用した人の誘導を検討したい.

\section{謝辞}

本研究は, JST CREST「先進的統合センシング技 術」の補助を受け遂行されたものである。ここに謝意 を表する。

\section{参 考 文 献}

［1］高橋雅人, 林貴宏, 尾内理紀夫：“振り”の練習を支 援するインタラクティブシステム,インタラクション 2004 論文集, 情報処理学会シンポジウムシリーズ, Vol.2004, No.5, pp.97-104, 2004

［2］杉本麻樹, 渡邊淳司, 安藤英由樹, 前田太郎: 前庭感 覚刺激による歩行方向の誘導パラサイトヒューマンの 研究第 17 報, 日本バーチャルリアリティ学会大会論 文集， 8, pp.339-342, Sep.2003

[ 3 ] Richard C. Fitzpatrick and Brian L. Day : Probing the human vestibular system with galvanic stimulation, J Appl Physiol 96 : 2301-2316, 2004

[4] 内野善生：めまいと平衡調節，金原出版，2002

[ 5 ] 深田栄一, 井上四朗: 生体電気刺激, 共立出版株式会 社, 1989

［6］永谷直久, 杉本麻樹, 北崎充晃, 稲見晶彦：前庭感覚 電気刺激の視界に及ぼす効果, 電子情報通信学会技術 報告, MVE2006-12, pp.85-88, 2005

[ 7 ] J. P. Bresciania, J. Blouina, K. Popovb, C. Bourdina, F. Sarlegnaa, J. L. Verchera, G.M. Gauthiera : Galvanic vestibular stimulation in humans produces online arm movement deviations when reaching towards memorized visual targets, Neuroscience Letters, 318, pp.3438,2002

[ 8 ] 安藤英由樹, 渡邊淳司, 杉本麻樹, 前田太郎: 前庭感 覚インタフェース技術の理論と応用,情報処理学会論 文誌，Vol.48，No.3，pp.1326-1335，2007

[9] 前田太郎：身体活用インタフェース, The Japanese Journal of Psychonomic Science, Vol.24, No.1, pp. 100106, 2005

[10] Guedy F E : Psychophysics of vestibular sensation, Handbook of Sensory Physiology VI/2. Part 2. Vestibular System Psychophysics Applied Aspects and General Interpretations, pp.1-154, Springer-Verlag, 1974

[11] T. Murofushi, S. Iwasaki, H. Ozeki, M. Ushio, Y. Chihara: Tone burst-galvanic ratio of vestibular evoked myogenic potential amplitudes : a new parameter of vestibular evoked myogenic potential?, Clin Neurophysiol, 118 (8), pp.1685-1690, 2007

[12] Y. Chihara, S. Iwasaki, M. Ushio, T. Murofushi : Vestibular-evoked extraocular potentials by air-conducted sound : another clinical test for vestibular function, Clin Neurophysiology, 118 (12), pp.2745-2251, 2007

[13] N. Watanabe, T. Omori : Trigger Model for Guiding Arm Movement in Circle Drawing, Proc. IEEE\&INNS/ FUZZ'10 (WCCI'10), pp.18-23, 2010

[14] 樋口貴広, 森岡周: 身体運動学一知覚·認知からのメッ セージ，三輪書店，2008

[15］浅野美帆, 桑原雅夫, 田中伸治：混雑時に打けるミク 口歩行者流動モデルの構築, 第 5 回ITSシンポジウム 講演集，2006

[16] Natalie Fridman, Gal A. Kaminka : Towards a Cognitive Model of Crowd Behavior Based on Social Comparison Theory, AAAI 2007, pp.731-737, 2007

[17］中村怜史, 村田和人, 渡辺仁史：博覧会におけるすれ 違い行動に関する研究, 日本建築学会大会学術講演梗 概集 (関東)，2006

[18］土屋和夫, 高草木薫, 萩原直道:【シリーズ移動知】第 2 巻 身体適応一歩行運動の神経機構とシステムモデ ル, オーム社, 2010

(2010年 5 月16日 受付)

(2011年12月29日 採録)

[問い合わせ先]

于 194-8610 東京都町田市玉川学園6-1-1

玉川大学脳科学研究所

渡邊 紀文

TEL : 042-739-8672

FAX : 042-739-8672

E-mail : norifumi@lab.tamagawa.ac.jp 


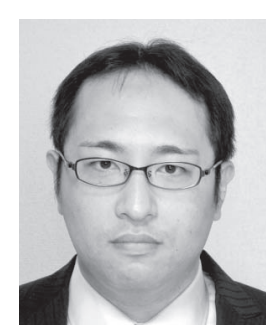

\section{渡邊 紀文 $[$ 正会員 $]$}

2008 年慶應義塾大学大学院 政策 · メディア研究科後期博士課程修了, 博 士 (政策・メディア)。2008年玉川大 学脳科学研究所知能ロボット研究セン タ一嘱託研究員, 現在に至る. 視覚情 報処理に関する神経回路モデルの研究 に従事, 近年は, 眼球運動及びモー ションキャプチャ計測等を行い, 人間 の錯覚を利用した行動誘導について模 索している.日本知能情報ファジィ学 会, 日本神経回路学会, 人工知能学会 各会員.

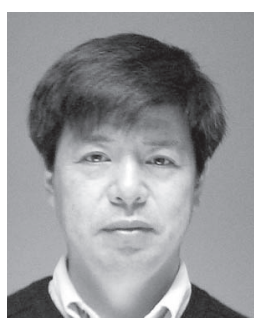

大势架 绦司 [非会員]

1980 年東京大学工学研究科修了, 1981 年より東京大学助手, 87 年東京 農工大学工学部講師を経て 88 年より 同助教授, 98 年同大学電気電子工学 科教授, 2000 年北海道大学大学院工 学研究科教授を経て, 2006 年 4 月より 玉川大学教授, 現在にいたる。博士 (工学)。この間, 89-90 年ブラウン大 学言語と認知学科客員研究員. 脳とい う神経機構に知的な行動が生まれる情 報的なメカニズムに興味があり, 認知 科学, 人工知能, 発達, 神経科学など の諸学問を足をつっこみながら, 心に 関わる脳の情報処理の解明と工学的な 方法による実現を試みている.計測自 動制御学会, 日本認知科学会, 日本神 経回路学会, 電子情報通信学会などの 会員.

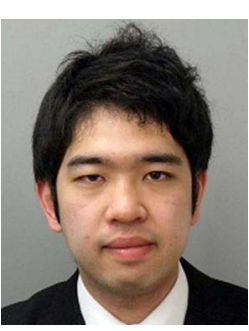

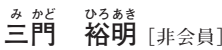

2010 年玉川大学工学部メディア ネットワーク学科卒業. 現在玉川大学 大学院工学研究科電子情報工学専攻修 士課程在学中. 歩行者の誘導を目指し た行動決定過程の研究に従事. 


\section{Guiding Effect of Human Waking and Behavioral Decision Model by \\ Galvanic Vestibular Stimulation}

by

\section{Norifumi WATANABE, Hiroaki MIKADO and Takashi OMORI}

\section{Abstract :}

We decide and execute our action from many types of environmental information in our daily lives even if we are not conscious of being guided. Galvanic Vestibular Stimulation (GVS) is known as a method of giving influence on sense of equilibrium. The vestibular system is stimulated by a weak current through an electrode placed on the mastoid behind the ear. In this paper, we had a motion guidance experiment of walking by using GVS to evaluate the effect. Next, we experimented on the behavioral decision process in human walking phase so that the GVS might influence it more effectively. We make an experiment to judge the avoidance direction by watching the masking movie of oncoming person's body part. From this result, the avoidance judgment is possible because the traveling direction can be controlled by the leg when the leg is lifting and landing. It was clarified that oncoming person's walking phase is important in the behavioral decision in collision avoidance. So we propose the behavioral decision model based at the walking phase.

Keywords : Galvanic Vestibular Stimulation, Walking Guidance, Collision Avoidance, Behavioral Decision

\section{Contact Address : Norifumi WATANABE}

Tamagawa University Brain Science Institute

6-1-1, Tamagawa Gakuen, Machida-shi, Tokyo, 194-8610, JAPAN

TEL : :042-739-8672

FAX :042-739-8672

E-mail : norifumi@lab.tamagawa.ac.jp 